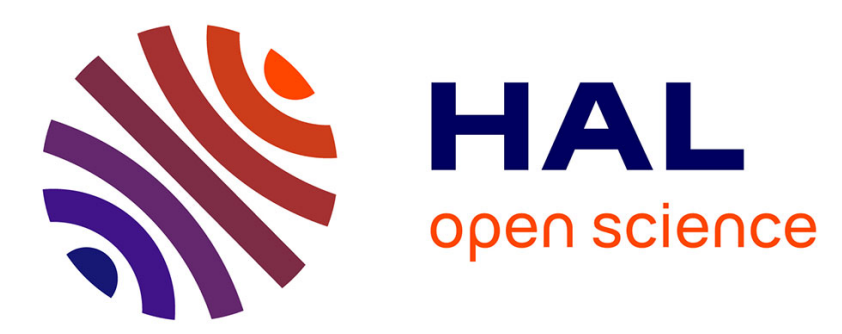

\title{
Pure stands of temperate forest tree species modify soil respiration and $\mathrm{N}$ turnover
}

N. Brüggemann, P. Rosenkranz, H. Papen, K. Pilegaard, K. Butterbach-Bahl

\section{To cite this version:}

N. Brüggemann, P. Rosenkranz, H. Papen, K. Pilegaard, K. Butterbach-Bahl. Pure stands of temperate forest tree species modify soil respiration and $\mathrm{N}$ turnover. Biogeosciences Discussions, 2005, 2 (2), pp.303-331. hal-00297740

\section{HAL Id: hal-00297740 \\ https://hal.science/hal-00297740}

Submitted on 6 Apr 2005

HAL is a multi-disciplinary open access archive for the deposit and dissemination of scientific research documents, whether they are published or not. The documents may come from teaching and research institutions in France or abroad, or from public or private research centers.
L'archive ouverte pluridisciplinaire HAL, est destinée au dépôt et à la diffusion de documents scientifiques de niveau recherche, publiés ou non, émanant des établissements d'enseignement et de recherche français ou étrangers, des laboratoires publics ou privés. 
Pure stands of

\section{temperate forest tree} species

N. Brüggemann et al.

\section{Pure stands of temperate forest tree species modify soil respiration and $\mathrm{N}$ turnover}

N. Brüggemann ${ }^{1}$, P. Rosenkranz ${ }^{1}$, H. Papen ${ }^{1}$, K. Pilegaard ${ }^{2}$, and K. Butterbach-Bahl ${ }^{1}$

${ }^{1}$ Forschungszentrum Karlsruhe, Institute for Meteorology and Climate Research, Atmospheric Environmental Research (IMK-IFU), Garmisch-Partenkirchen, Germany

${ }^{2}$ Risø National Laboratory, Plant Biology and Biogeochemistry Department, Roskilde, Denmark

Received: 17 February 2005 - Accepted: 18 March 2005 - Published: 6 April 2005

Correspondence to: N. Brüggemann (nicolas.brueggemann@imk.fzk.de)

(C) 2005 Author(s). This work is licensed under a Creative Commons License.

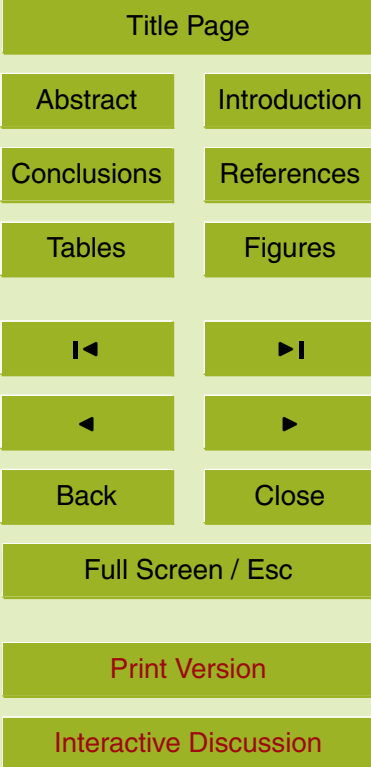




\section{Abstract}

The effects of five different tree species common in the temperate zone, i.e. beech (Fagus sylvatica L.), pedunculate oak (Quercus robur L.), Norway spruce (Picea abies [L.] Karst), Japanese larch (Larix leptolepis [Sichold and Zucc.] Gordon) and mountain 5 pine (Pinus mugo Turra), on soil respiration, gross $\mathrm{N}$ mineralization and gross nitrification rates were investigated. Soils were sampled in spring and summer 2002 at a forest trial in Western Jutland, Denmark, where pure stands of the five tree species of the same age were growing on the same soil. Soil respiration, gross rates of $\mathrm{N}$ mineralization and nitrification were significantly higher in the organic layers than in the $A_{h}$ horizons for all tree species and both sampling dates. In summer (July), the highest rates of soil respiration, gross $\mathrm{N}$ mineralization and gross nitrification were found in the organic layer under spruce, followed by beech $>$ larch $>$ oak $>$ pine. In spring (April), these rates were also higher under spruce compared to the other tree species, but were significantly lower than in summer. For the $A_{h}$ horizons no clear seasonal trend

15 was observed for any of the processes examined. A linear relationship between soil respiration and gross $\mathrm{N}$ mineralization $\left(r^{2}=0.77\right)$, gross $\mathrm{N}$ mineralization and gross $\mathrm{ni}$ trification rates $\left(r^{2}=0.72\right)$, and between soil respiration and gross nitrification $\left(r^{2}=0.81\right)$ was found. The results obtained underline the importance of considering the effect of forest type on soil $\mathrm{C}$ and $\mathrm{N}$ transformations.

\section{Introduction}

Forests in general have a greater influence on soil conditions than most of the other plant ecosystem types, e.g. by a well developed $O$ horizon, moderating temperature and humidity at the soil surface, input of litter with high lignin content, but also by high total net primary production and high water and nutrient demand (Binkley and Giardina, 1998). Moreover, different tree species can differ significantly in their influence on soil properties as well as on soil fertility (Augusto et al., 2002). They can differ e.g. in
BGD

2, 303-331, 2005

Pure stands of temperate forest tree species

N. Brüggemann et al.

\section{Title Page}

Abstract Introduction

Conclusions References

Tables Figures

14

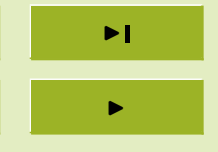

Back

Close

Full Screen / Esc

Print Version

Interactive Discussion

EGU 
quantity and quality of litter input to the soil, the influence on the physical soil properties (temperature, water content, $\mathrm{pH}$ ), the amount of atmospheric deposition of $\mathrm{S}, \mathrm{N}$ and $\mathrm{H}^{+}$ in polluted areas, in promoting mineral weathering by exudates and pedogenesis, and in $\mathrm{N}_{2}$ fixation (Binkley and Giardina, 1998). An effect of tree species on soil microbial 5 biomass has also been described, with concentrations of microbial $\mathrm{C}$ and $\mathrm{N}$ being lower in forest floor beneath conifers than beneath deciduous tree species (Bauhus et al., 1998). Likewise, soils of deciduous stands showed higher $\mathrm{N}$ mineralisation than soils of coniferous stands (Coté et al., 2000), probably due to differences in foliage litter quality, as net $\mathrm{N}$ mineralisation was found to decrease strongly with increasing lignin content

and with increasing lignin to $\mathrm{N}$ ratio (Scott and Binkley, 1997). A comparable pattern has been found for net nitrification rates, i.e. high rates under deciduous species and low or not detectable rates under coniferous tree stands (Ste-Marie and Paré, 1999).

To our knowledge, only few studies have been made in which different $\mathrm{N}$ transformation processes in soils under different tree species/forest types were investigated simultaneously. E.g., Erickson et al. (2002) studied net rates of $\mathrm{N}$ mineralisation and nitrification in dry tropical forest, and Menyailo et al. (2003) investigated basal and substrate-induced respiration rates, net $\mathrm{N}$ mineralization and net nitrification rates, denitrification as well as production and consumption of $\mathrm{N}_{2} \mathrm{O}$ in a Siberian afforestation experiment. A similar comprehensive study for the temperate climate region has not been reported up to now. Therefore, the aim of the present work was to assess a potential effect of pure stands of five different temperate tree species on soil respiration as well as on gross rates of mineralisation and nitrification in samples of the organic layers and the $A_{h}$ horizons to reduce the uncertainty about the influence of tree species on soil $\mathrm{C}$ and $\mathrm{N}$ turnover processes and of the associated formation of $\mathrm{C}$ and $\mathrm{N}$ trace gases. This knowledge is essential for the development of reliable process-oriented biogeochemical models for the simulation of ecosystem $\mathrm{C}$ and $\mathrm{N}$ turnover, $\mathrm{C}$ and $\mathrm{N}$ trace gas exchange, as well as of vegetation dynamics.
BGD

2, 303-331, 2005

Pure stands of temperate forest tree species

N. Brüggemann et al.

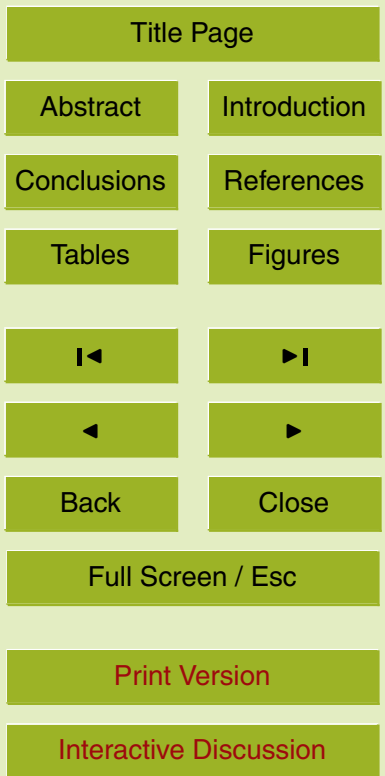

EGU 


\section{Materials and methods}

2.1. Location of the sampling area

The study site is part of a tree species trial in Western Jutland, Denmark $\left(56^{\circ} 17^{\prime} 27^{\prime \prime} \mathrm{N}\right.$, $8^{\circ} 25^{\prime} 40^{\prime \prime} \mathrm{E}$ ), established in 1965 on a sandy heathland by ploughing the soil $50-60 \mathrm{~cm}$ 5 deep, fertilizing it with approx. $240 \mathrm{~kg} \mathrm{Pha}^{-1}$ and sowing $100 \mathrm{~kg} \mathrm{ha}^{-1}$ lupine seeds. For soil improvement black alder (Alnus glutinosa L.) plants were added to each of the different tree species, but were removed during the following few years, resulting in monospecific tree stands $(50 \mathrm{~m} \times 60 \mathrm{~m})$. The sampling area is part of the cooltemperate climate region, with an annual mean air temperature of $7.7^{\circ} \mathrm{C}$ and an annual mean precipitation of $960 \mathrm{~mm}$. The soils of the region are dominated by podzols on sandy siliceous substrate. The mean annual wet deposition of $\mathrm{N}$ to the soil amounts to approx. $15 \mathrm{~kg} \mathrm{~N} \mathrm{ha}^{-1}$ (Andersen et al., 2003).

\subsection{Soil sampling}

Soil samples were taken on 23 April, 2002, and on 2 July, 2002 from soils under beech 15 (Fagus sylvatica L.), pedunculate oak (Quercus robur L.), Norway spruce (Picea abies
[L.] Karst), Japanese larch (Larix leptolepis [Sichold and Zucc.] Gordon) and mountain pine (Pinus mugo Turra). On each date samples were taken from six defined locations (Fig. 1) under each of the tree species, differentiating between the organic layer and the $A_{h}$ horizon to a depth of $5 \mathrm{~cm}$. Each sample consisted of approx. $2 \mathrm{~kg}$ of organic layer and of $A_{h}$ horizon, respectively, and was temporally stored in plastic bags, perforated with small holes to ensure gas exchange, but to minimize drying of the soil. The soil samples were transferred within $1 \mathrm{~d}$ to the microbiological labs of the Institute for Meteorology and Climate Research, Garmisch-Partenkirchen, Germany, and stored in a dark room at $4^{\circ} \mathrm{C}$ until analysis. In each of the following weeks, samples from identical sampling positions in each of the five tree stands were processed, so that within 6 weeks after sampling all samples of the one sampling event had been processed.
BGD

2, 303-331, 2005

Pure stands of temperate forest tree species

N. Brüggemann et al.

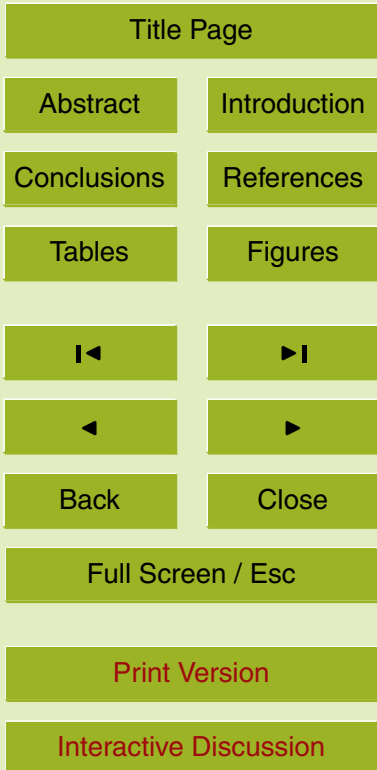

EGU 
Soil temperatures at $5 \mathrm{~cm}$ depth were determined at both samplings and at each sampling location with a soil thermometer (TTX 290S, Ebro, Ingolstadt, Germany). The thickness of the organic layer under each of the tree species was measured at the first 5 sampling.

The maximum water holding capacity (MWHC), the total organic $\mathrm{C}$ and the $\mathrm{N}$ contents of the different soils were determined on three mixed samples of the organic layers and the $A_{h}$ horizons, respectively, for each of the different stands. For the determination of the MWHC, the $\mathrm{C}$ and $\mathrm{N}$ contents, but also for the analysis of soil $\mathrm{C}$ and

$\mathrm{N}$ turnover rates, the samples of the $A_{h}$ horizon were sieved $<3.15 \mathrm{~mm}$, whereas the samples of the organic layers were sieved $<4 \mathrm{~mm}$. Two different mesh sizes were used in order to (i) homogenize the samples for a reproduceable analysis especially of gross $\mathrm{N}$ mineralization rates, as the ${ }^{15} \mathrm{~N}$ label solution had to be distributed evenly within the samples, and (ii) preserve as much of the soil structure as possible to minimize disturbance of the samples.

The MWHC was quantified as follows: approx. $50 \mathrm{~g}$ of the sieved soil was transferred into a filter mask (Sanifil, Roth, Karlsruhe, Germany) that was placed in a funnel closed with a stopcock at the bottom. Thereafter the soil was covered with water and allowed to become water-saturated. The stopcock was opened, so that the excess of water could run off. When there was no more water released by the soil samples within $1 \mathrm{~h}$, they were transferred into a glass vial, weighed, oven-dried for $24 \mathrm{~h}$ at $105^{\circ} \mathrm{C}$, and then their dry weights were determined. The difference between water-saturated and dry soil, calculated for $100 \mathrm{~g}$ dry soil, was taken as the MWHC. Aliquots of the soil samples were sent out to a commercial laboratory (Laboratory Dr. Janssen, Gillersheim, Germany), where the total organic $\mathrm{C}$ and the $\mathrm{N}$ contents of the samples were quantified.

The $\mathrm{pH}$ values of the soil samples were determined as follows: $10 \mathrm{~g}$ soil were taken from each sample, sieved and transferred into a closable polyethylene (PE) test tube. Then $25 \mathrm{ml}$ of $10 \mathrm{mM} \mathrm{CaCl}_{2}$ solution were added, and the mixture was stirred for $30 \mathrm{~min}$

Pure stands of temperate forest tree species

N. Brüggemann et al.

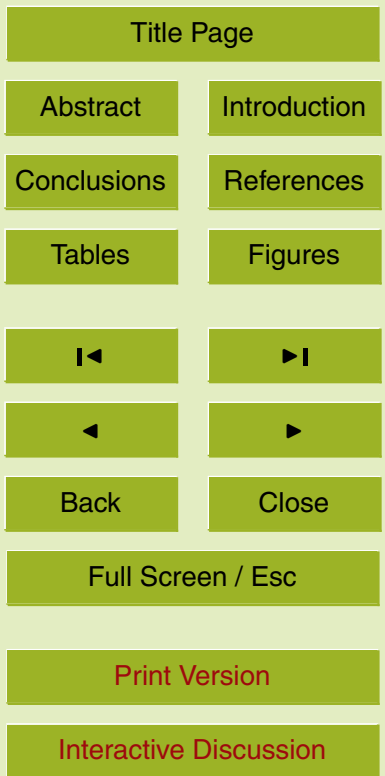

EGU 
on a rotary shaker at 200 rev $\min ^{-1}$. The $\mathrm{pH}$ value of the suspension was determined with a $\mathrm{pH}$ meter (WTW, Weilheim, Germany).

\subsection{Determination of gross $\mathrm{N}$ mineralization rates}

Gross N mineralisation rates were determined using the ${ }^{15} \mathrm{~N}$ isotope pool dilution tech5 nique, modified after Davidson et al. (1991). Prior to ${ }^{15} \mathrm{~N}$ labeling the soils were sieved manually and moistened to a water content of $60 \%$ of their respective MWHC. For ${ }^{15} \mathrm{~N}$ labeling a $2.5 \mathrm{mM}\left({ }^{15} \mathrm{NH}_{4}\right)_{2} \mathrm{SO}_{4}$ solution with 6 at\% ${ }^{15} \mathrm{~N}$ was used. The solution was prepared by mixing ammonium sulfate with natural abundance of ${ }^{15} \mathrm{~N}$ (Merck, Darmstadt/Germany) with ammonium sulfate with an enrichment of 95 at $\%{ }^{15} \mathrm{~N}$ (Chemo10 trade, Leipzig/Germany). For labeling approx. $200 \mathrm{~g}$ soil was spread out in a plastic tray, and $3 \mathrm{ml}$ labeling solution per $100 \mathrm{~g}$ of soil were added in a grid pattern with a $5 \mathrm{ml}$ PE syringe equipped with a $0.4 \mathrm{~mm}$ steel cannula. During the labeling procedure the soil was mixed several times to ensure homogenous labeling with ${ }^{15} \mathrm{~N}$. Immediately after labeling the exact water content of the soil was determined gravimetrically. Subse15 quently, six PE test tubes were filled each with $20 \mathrm{~g}$ of the labeled soil and sealed with Parafilm (American National Can, Greenwich, USA). The test tubes were stored in a refrigerator at $12^{\circ} \mathrm{C}$ for at least $20 \mathrm{~h}$ to condition the soil to the assay conditions. Then $\left(t_{1}\right)$ three of the six parallels were transferred to $250 \mathrm{ml}$ wide-necked PE flasks, and $60 \mathrm{ml}$ of $1 \mathrm{M} \mathrm{KCl}$ solution were added. The samples were stirred on a rotary shaker 20 at $150 \mathrm{rev} \mathrm{min}^{-1}$ for $30 \mathrm{~min}$. The suspension was filtered through a fiber glass filter (Whatman GF/A, Springfield Mill, UK). $10 \mathrm{ml}$ of the filtrate were removed with a $30 \mathrm{ml}$ PE syringe equipped with a syringe filter $(0.2 \mu \mathrm{m}$, Schleicher \& Schuell, Dassel, Germany), transferred to a $15 \mathrm{ml} \mathrm{PE}$ test tube, stored at $-20^{\circ} \mathrm{C}$ and sent out for colorimetric analysis of the ammonium concentration (Laboratory Dr. Janssen, Gillersheim, 25 Germany). Another $30 \mathrm{ml}$ of the filtrate were transferred with the same syringe into a $250 \mathrm{ml}$ wide-necked glass flask for the analysis of the ${ }^{14 / 15} \mathrm{~N}$ isotope ratio. The other three parallels were kept in the refrigerator at $12^{\circ} \mathrm{C}$ for additional $24 \mathrm{~h}\left(t_{2}\right)$, and then

\section{Pure stands of temperate forest tree species}

N. Brüggemann et al.




treated in the same way as the first set.

The ${ }^{14 / 15} \mathrm{~N}$ isotope ratio was determined according to the diffusion method of Brooks et al. (1989), by which the $\mathrm{NH}_{4}^{+}$is driven out into the gas phase as $\mathrm{NH}_{3}$ under alkaline conditions and captured by an acidified solid phase. To alkalize the solution $250 \mathrm{mg}$ 5 of $\mathrm{MgO}$ (Merck, Darmstadt, Germany), annealed for $12 \mathrm{~h}$ at $1000^{\circ} \mathrm{C}$ prior to use to remove any $\mathrm{N}$ compounds, and a small glass ball to ensure an even distribution of the $\mathrm{MgO}$ were added to the $30 \mathrm{ml}$ of filtrate. The flasks were closed air-tight with a silicone seal ring, a stainless steel cap with a hook at the bottom and finally with a screw cap. A small piece of fiber glass filter (Whatman GF/A, Springfield Mill, UK), punched out of a filter with an office puncher and treated with $10 \mu \mathrm{l}$ of $2.5 \mathrm{M} \mathrm{KHSO}_{4}$, was attached to the hook in the interior of the flask. The closed flasks were shaken on a rotary shaker at $140 \mathrm{rev} \mathrm{min}^{-1}$ for $24 \mathrm{~h}$ in the dark at $28^{\circ} \mathrm{C}$. Thereafter the small filter pieces were removed carefully and transferred into a 96 -well microplate, which was placed into a desiccator. The filter pieces were dried in the dark over silica gel at $4^{\circ} \mathrm{C}$. Finally, 15 the ${ }^{14 / 15} \mathrm{~N}$ isotope ratio of the $\mathrm{NH}_{4}^{+}$was determined at the Risoe National Laboratory (Roskilde, Denmark) with an elemental analyzer (EA 1110, Carlo Erba Instruments, Milan, Italy) connected to an isotope ratio mass spectrometer (MAT Delta Plus, Thermo Finnigan, Bremen, Germany). Gross N mineralization rates were calculated according to the equations of Kirkham and Bartholomew (1954).

\subsection{Determination of soil respiration and gross nitrification rates}

Soil $\mathrm{CO}_{2}$ formation and gross nitrification rates were determined using the barometric process separation method (BaPS, Ingwersen et al., 1999). This method is based on the determination of the $\mathrm{CO}_{2}^{-}, \mathrm{O}_{2}$ - and total gas balance of well aerated soil samples in an isothermal gas tight soil system. In such a system the processes of nitrification (net consumption of $\mathrm{O}_{2}$ - pressure decrease), denitrification (net $\mathrm{CO}_{2}$ production and net production of $\mathrm{NO}, \mathrm{N}_{2} \mathrm{O}$ and $\mathrm{N}_{2}$ - pressure increase), soil respiration (pressure neutral if the respiration coefficient equals 1 ) and $\mathrm{CO}_{2}$ dissolution in the soil water (pressure

\section{Pure stands of temperate forest tree species}

N. Brüggemann et al.




decrease) are the only pressure relevant processes. Based on the total gas balance of such a system an inverse balancing approach can be used to calculate rates of nitrification, denitrification and $\mathrm{C}$ mineralization. For further details see Ingwersen et al. (1999), Breuer et al. (2002) and Kiese et al. (2002).

5 For the BaPS experiments approx. $700 \mathrm{ml}$ of sieved soil were moistened to $60 \%$ MWHC. After covering the soil with perforated plastic foil, the soil was placed into a refrigerator at $12^{\circ} \mathrm{C}$ for $12 \mathrm{~h}$ to allow the soil to adapt to the incubation temperature. Thereafter the soil was filled into the reaction chamber of the BaPS instrument (UMS, München, Germany). After gas-tight closure of the lid the instrument was placed in a 10 thermostatic water bath at $12^{\circ} \mathrm{C}$ for at least $7 \mathrm{~h}$. During the entire duration of the measurements air and soil temperature as well as the values for air pressure and for $\mathrm{CO}_{2}$ and $\mathrm{O}_{2}$ concentration were monitored continuously by the instrument sensors. The data were aggregated as $10 \mathrm{~min}$ means. At the end of the measurements the exact water content of the soil was determined gravimetrically. Rates of soil respiration and gross nitrification were calculated using the software delivered with the BaPS instrument (UMS, München, Germany) on the theoretical basis described by Ingwersen et al. (1999).

\subsection{Statistical analysis}

Statistical analyses of the significance of differences between the different soils orig20 inating from the different tree stands, the two different sampling dates and the two different soil layers were performed using SPSS 8.0 for Windows (SPSS Inc., Chicago, USA). For the analyses of variance between the different tree species and the different sampling dates a one-way ANOVA, including the Bonferroni Post-Hoc test, was applied, and for the differences between the organic layer and the mineral layer the paired t-test was used.

\section{BGD}

2, 303-331, 2005

Pure stands of temperate forest tree species

N. Brüggemann et al.

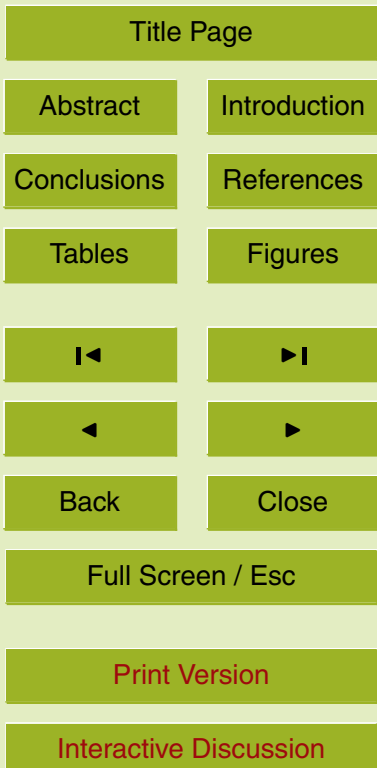

EGU 


\section{Results}

The thickness of the organic layer was considerably different between the tree species studied (Table 1), with the organic layer under larch being thickest, followed by beech,

5 spruce, pine and oak. The organic layer under oak was approximately half as thick as under larch. Soil temperatures were also different between the different stands and the two sampling dates (Table 1). In April as well as in July the values were significantly lower for the soil under spruce and beech as compared to oak, pine and larch. The water contents at the time of sampling were always higher in the organic layers than in the respective $A_{h}$ horizons (Table 2), and were always higher in the July samples than in the April samples. In April as well as in July the water content in the organic layer under beech was highest, whereas it was lowest in the $A_{h}$ horizon under spruce in April and under larch in July. Similar tendencies were found for the MWHC (Table 2). The values of MHWC of the organic layer were also always significantly higher than those of the $A_{h}$ horizon at both sampling dates, and the MWHC of the organic layer samples taken in July were always higher than those taken in April. With $741.8 \mathrm{~g} \mathrm{H}_{2} \mathrm{O}$ $\mathrm{g}^{-1}$ soil dry weight (sdw) the organic layer under larch had the highest MWHC in April, being significantly higher than the MWHC of soil under all other tree species studied. In July the organic layer under beech showed the highest value $\left(832.8 \mathrm{~g} \mathrm{H}_{2} \mathrm{O} \mathrm{g}^{-1} \mathrm{sdw}\right)$, followed by larch, spruce, pine and oak. For the $A_{h}$ horizon no such clear tendencies could be observed: whilst spruce had the lowest MWHC in April $\left(56.7 \mathrm{~g} \mathrm{H}_{2} \mathrm{O} \mathrm{g}^{-1}\right)$, it showed the highest value in July $\left(62.8 \mathrm{~g} \mathrm{H}_{2} \mathrm{O} \mathrm{g}^{-1} \mathrm{sdw}\right)$.

The $\mathrm{pH}$ values of all soil samples were in the range of 3.1 to 3.5 , thus being very acidic, and with the $\mathrm{pH}$ of the organic layers always being slightly lower than that of the $A_{h}$ horizons (Table 3 ). The total organic $\mathrm{C}$ contents of the organic layers ranged between $29.3 \%$ for pine and $49.3 \%$ for larch, those of the $A_{h}$ horizons between $2.5 \%$ (larch) and $4.4 \%$ (beech), albeit the differences within each of the layer types were

\section{Pure stands of temperate forest tree species}

N. Brüggemann et al.

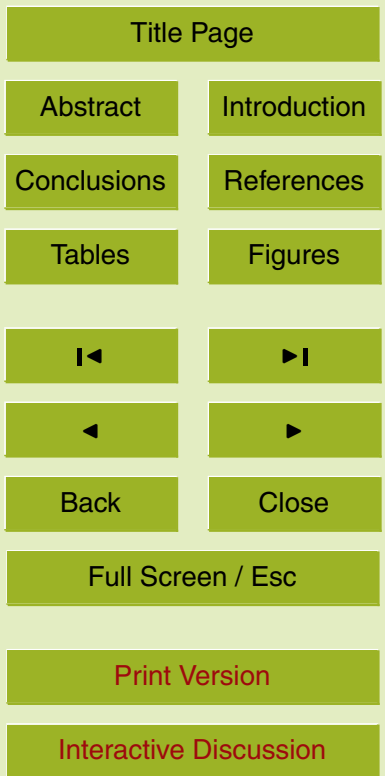

EGU 
not significant (Table 3). The total $\mathrm{N}$ contents of the organic layers were in the range of $1.4 \%$ to $2.3 \%$, with the lowest value for pine and the highest value for beech. The lowest $\mathrm{N}$ content of the $A_{h}$ horizons was found for larch $(0.13 \%)$, whereas the highest was found again for beech $(0.21 \%)$. Also the differences in $\mathrm{N}$ contents were not significant 5 in both the organic layers and the $A_{h}$ horizons. The resulting $\mathrm{C}$ to $\mathrm{N}$ ratios of the organic layers as well as in the $A_{h}$ horizons were in the range of 17.6 to 23.3 , except for the organic layer under larch, where the $C$ to $N$ ratio amounted to 28.6 , which was significantly higher than all other values.

\subsection{Soil respiration rates}

10 Soil respiration rates in the organic layer were considerably higher in July than in April under all five tree species (Fig. 2a). In April, the highest rates were determined for organic layer samples from the spruce site $\left(178.7 \mathrm{mg} \mathrm{C} \mathrm{kg}^{-1} \mathrm{sdw} \mathrm{d}^{-1}\right)$, followed by larch, beech, pine and oak, but the differences remained insignificant $(P>0.05)$. In July, organic layer samples from the spruce site exhibited the signifi15 cantly highest rates $\left(345.7 \mathrm{mg} \mathrm{C} \mathrm{kg}^{-1} \mathrm{sdw} \mathrm{d}^{-1}\right)$, followed by samples from the beech site $\left(240.2 \mathrm{mg} \mathrm{C} \mathrm{kg}^{-1} \mathrm{sdw} \mathrm{d}^{-1}\right)$, which in turn showed a significantly higher respiration than the organic layers under larch, oak and pine.

In the $A_{h}$ horizons, respiration rates were 8-fold (oak in April) to 35-fold (larch in July) lower than in the respective organic layers. In contrast to the organic layers, no clear 20 seasonal change of respiration rates was detected (Fig. 3a), but again the mineral soil under spruce had the highest rates in April (14.9 $\left.\mathrm{mg} \mathrm{C} \mathrm{kg}^{-1} \mathrm{sdw} \mathrm{d}^{-1}\right)$ as well as in July (12.1 $\mathrm{mg} \mathrm{C} \mathrm{kg}^{-1} \mathrm{sdw} \mathrm{d}^{-1}$ ), being significantly higher than in the mineral soils from oak, pine and larch in April, and only larch in July.

\subsection{Gross $\mathrm{N}$ mineralization rates}

25 In soils from all stands gross $\mathrm{N}$ mineralization rates in the organic layers were, like the soil respiration rates, generally higher in July than in April (Fig. 2b), with the differences

Pure stands of temperate forest tree species

N. Brüggemann et al.

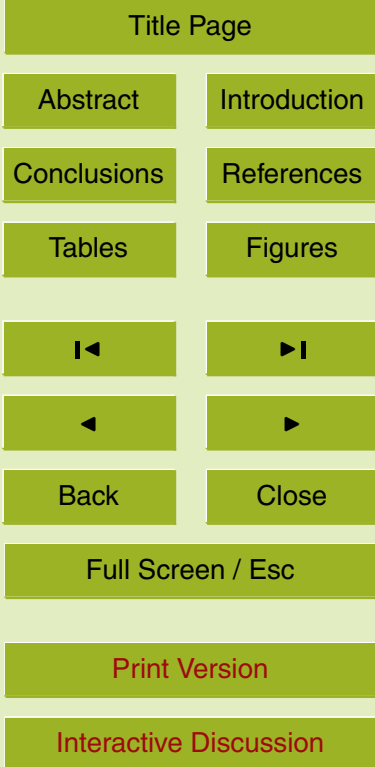

EGU 
for the beech and spruce stands being significant $(P<0.05)$. The lowest gross $\mathrm{N}$ mineralization rate in April was determined for soil under beech $\left(6.2 \mathrm{mg} \mathrm{N} \mathrm{kg}^{-1} \mathrm{sdw} \mathrm{d}^{-1}\right)$, whereas the highest rate was found for soil under spruce $\left(12.9 \mathrm{mg} \mathrm{N} \mathrm{kg}^{-1} \mathrm{sdw} \mathrm{d}^{-1}\right)$, albeit being not significantly higher than those found for the other tree species. The low5 est gross $\mathrm{N}$ mineralization rate in July was detected under pine $\left(8.9 \mathrm{mg} \mathrm{N} \mathrm{kg}^{-1} \mathrm{sdw} \mathrm{d}^{-1}\right)$, being significantly lower than in the organic layer under spruce, that again exhibited the highest rate $\left(25.1 \mathrm{mg} \mathrm{N} \mathrm{kg}^{-1} \mathrm{sdw} \mathrm{d}^{-1}\right)$.

Gross $\mathrm{N}$ mineralization rates in the $A_{h}$ horizons were highly significantly $(P<0.001)$ lower than rates in the organic layers under all tree species studied (Fig. 3b), with the

10 rates in the organic layers being up to 35-fold (larch in July) higher than in the respective $A_{h}$ horizons. There was also no clear seasonal tendency for the magnitude of gross $\mathrm{N}$ mineralization in the $A_{h}$ horizons. The lowest value was found under larch in July $\left(0.5 \mathrm{mg} \mathrm{N} \mathrm{kg}^{-1} \mathrm{sdw} \mathrm{d} \mathrm{d}^{-1}\right)$, whereas the highest value was determined for soil under oak in April (1.3 $\mathrm{mg} \mathrm{N} \mathrm{kg}^{-1} \mathrm{sdw} \mathrm{d}^{-1}$ ). For soils under beech, oak and larch, the rates were 15 higher in April than in July, in contrast to the results obtained for the $A_{h}$ horizons under spruce and pine.

\subsection{Gross nitrification rates}

Gross nitrification rates in the organic layers showed a seasonal pattern similar to those of soil respiration and gross $\mathrm{N}$ mineralization rates (Fig. 2c), i.e. with higher rates in July than in April. The differences in rates of gross nitrification were significantly different between beech and spruce $(P<0.05)$. In April, the gross nitrification rates were lower for the soil under oak $\left(5.0 \mathrm{mg} \mathrm{N} \mathrm{kg}^{-1} \mathrm{sdw} \mathrm{d}^{-1}\right)$ than for the soils of the other four species, with the maximum value found for spruce $\left(11.8 \mathrm{mg} \mathrm{N} \mathrm{kg}^{-1} \mathrm{sdw} \mathrm{d}^{-1}\right)$. In July, the lowest gross nitrification rate was observed in the organic layer under pine $25 \quad\left(10.5 \mathrm{mg} \mathrm{N} \mathrm{kg}^{-1} \mathrm{sdw} \mathrm{d}^{-1}\right.$ ), being lower than under oak and larch, and significantly lower than under beech and spruce. Just as for the soil respiration and gross $\mathrm{N}$ mineralization rates, the organic layer under spruce exhibited also the highest gross nitrification rates $\left(40.0 \mathrm{mg} \mathrm{N} \mathrm{kg}^{-1} \mathrm{sdw} \mathrm{d}^{-1}\right.$ ).

\section{Pure stands of temperate forest tree species}

N. Brüggemann et al.

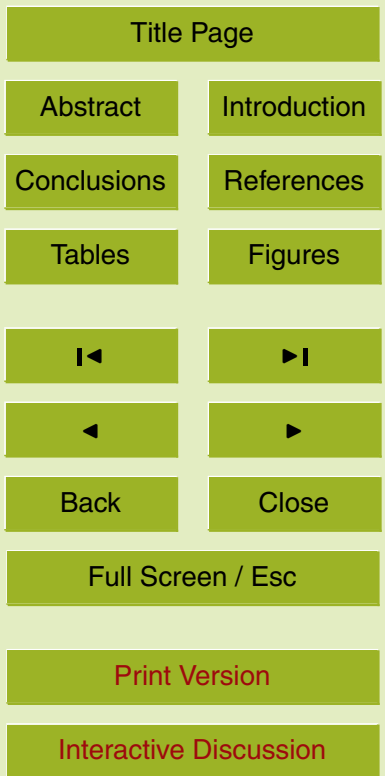

EGU 
Gross nitrification rates in the $A_{h}$ horizons under the five tree species studied were in the range of 0.5 to $1.2 \mathrm{mg} \mathrm{N} \mathrm{kg}^{-1} \mathrm{sdw} \mathrm{d}^{-1}$ (Fig. 3c), and again in all cases highly significantly $(P<0.001)$ lower than in the respective organic layer, that showed up to 54fold higher gross nitrification rates (beech in July). Analogous to the soil respiration and 5 gross $\mathrm{N}$ mineralization rates in the $A_{h}$ horizons, there was no clear seasonal change in gross nitrification rates. Although the values for pine were higher in July than in April, they were lower at the same time for beech, oak, spruce, and larch. Again, spruce showed the highest rates $\left(1.2 \mathrm{mg} \mathrm{N} \mathrm{kg}^{-1} \mathrm{sdw} \mathrm{d}{ }^{-1}\right.$ in April, and $1.1 \mathrm{mg} \mathrm{N} \mathrm{kg}^{-1} \mathrm{sdw} \mathrm{d}^{-1}$ in July), followed by larch, pine, oak and beech in April, and by pine, oak, beech and 10 larch in July. Like for the gross mineralization rates in the $A_{h}$ horizons, the differences between the means were not significant on the $P<0.05$ level.

\subsection{Relationships between soil respiration and gross $\mathrm{N}$ turnover rates}

Analyzing the relationships between soil respiration, gross $\mathrm{N}$ mineralization and gross nitrification for the different tree stands and soil layers separately revealed a set of different correlations (Table 4). In general, the interrelation between the three processes was more pronounced in the organic layer than in the $A_{h}$ horizon. Significant correlations between soil respiration and gross $\mathrm{N}$ mineralization were found for the organic layers under beech, larch and spruce. The weakest correlation between the two processes was observed for the organic layer under pine and for the $A_{h}$ horizon under oak. The highest, significant or even highly significant correlation coefficients were determined for the relationship between soil respiration and gross nitrification in the organic layers under all five tree species. Even in the $A_{h}$ horizons still close correlations between gross nitrification and soil respiration were found under beech and pine. The closest positive correlation between gross $\mathrm{N}$ mineralization and gross nitrification followed by the $A_{h}$ horizon beneath larch and the organic layer under spruce. In all the other soil samples the correlation was less pronounced.

BGD

2, 303-331, 2005

Pure stands of temperate forest tree species

N. Brüggemann et al.

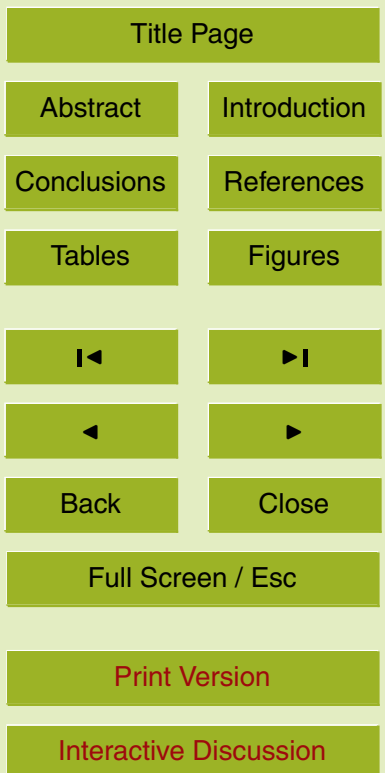

EGU 
Pooling all available data for one regression analysis resulted in highly significant positive correlations $(P<0.0001)$ between soil respiration and gross $\mathrm{N}$ mineralization (Fig. 4a), soil respiration and gross nitrification (Fig. 4b), and gross $\mathrm{N}$ mineralization and gross nitrification (Fig. 4c). Again, the closest relationship was found between 5 gross nitrification and soil respiration $\left(r^{2}=0.81\right)$, followed by gross $\mathrm{N}$ mineralization vs. soil respiration $\left(r^{2}=0.77\right)$ and gross nitrification vs. gross $\mathrm{N}$ mineralization $\left(r^{2}=0.72\right)$.

\section{Discussion}

\subsection{Soil variables}

The significant differences in soil respiration, gross $\mathrm{N}$ mineralization and gross nitrifi10 largely to the influences of the tree stands on the soil environment, since trees can
determine the biological, chemical and physical conditions in the soil (e.g. Muys and Lust, 1992; Priha et al., 1998, 1999; Binkley and Giardina, 1998; Priha and Smolander, 1999; Augusto et al., 2002). One of the factors governing the soil microbial processes

involved in decomposition and transformation of $\mathrm{C}$ and $\mathrm{N}$ containing compounds is the composition of the litter of the stand-forming tree species, i.e. mainly the $\mathrm{C}$ to $\mathrm{N}$ ratio as well as the lignin to N ratio of the leaves and needles (Gower and Son, 1992; Stump and Binkley, 1993; Scott and Binkley, 1997). The relatively persistent lignin plays an important role in $\mathrm{N}$ transformations, as it is converted preferentially into persistent humic substances during the process of humification, thereby additionally binding inorganic nitrogen compounds and making them unavailable for plants and microbes (Thomas and Prescott, 2000). Besides the quality, the quantity and the timing of litter fall also have crucial effects upon ground vegetation and microbial processes, especially when comparing deciduous with evergreen forests (e.g. Ferrari, 1999). The differences in the thickness of the litter layers of the tree stands we examined reflected this tree species influence.
BGD

2, 303-331, 2005

Pure stands of temperate forest tree species

N. Brüggemann et al.

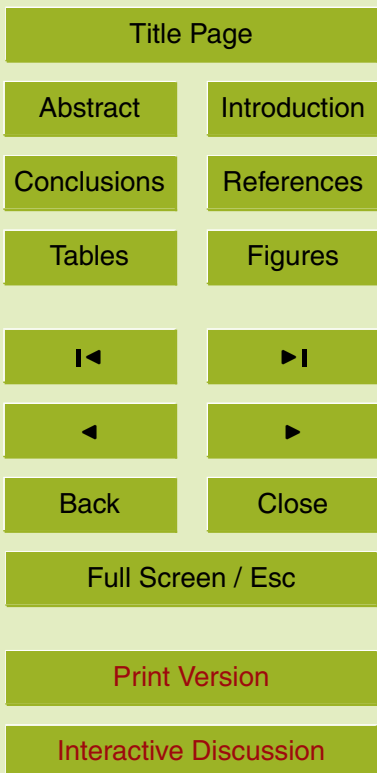

EGU 
The average soil temperature measured in our work during sampling was almost $5^{\circ} \mathrm{C}$ lower in April than in July. The soil surfaces under more translucent tree species, such as pine, oak and larch, receive more light and warm up more during the vegetation period than the soils beneath shadier tree species, such as beech and spruce. These 5 differences in the microclimate of the stands might be one of the potential causes for species-specific differences in $\mathrm{N}$ turnover rates.

Most of the soil samples were drier in April than in July due to an exceptionally dry period prior to the spring sampling event and a rainy period during the summer sampling. The amount and distribution of precipitation reaching the forest floor depends 10 upon the morphology of the stand-forming tree species. Especially needle-leaved trees are characterized by high interception in the crown region, leaving the soil remarkably drier than under broad-leaved deciduous trees (Binkley and Giardina, 1998). Furthermore, the spatial distribution of rainfall within a forest can vary greatly, depending on the tree species. For example, in a beech forest most of the precipitation entering the 5 crown region will reach the soil as stem flow, thereby mainly wetting the areas around the boles (Parker, 1983; Rothe, 1997). Although all soil samples were adjusted to the same moisture conditions $10 \mathrm{~h}$ before starting the experiments, it can take up to $16 \mathrm{~d}$ for microbial populations to adapt to the changed environmental conditions (Andrews et al., 2000). Thus, the history of both soil temperature and soil moisture were probably biasing $\mathrm{C}$ and $\mathrm{N}$ turnover rates, but the proportion of the bias attributable to one of the two factors could not be quantified. A bias of storing the samples on the magnitude of soil $\mathrm{C}$ and $\mathrm{N}$ turnover processes can be excluded, because on the one hand samples were treated in the same way and processed within the same time period after each sampling. On the other hand samples from identical sampling positions in each of the five tree stands were processed at the same time to eliminate any effect of storage.

The $\mathrm{C}$ to $\mathrm{N}$ ratios of the organic layers and the $A_{h}$ horizons matched the range of $\mathrm{C}$ to $\mathrm{N}$ ratios described to be typical for temperate forest ecosystems (e.g. Priha et al., 1998; Rustad et al., 2001; Michel and Matzner, 2002), with the $C$ to $N$ ratio of the organic layer under larch being significantly higher than under all other four tree species.
BGD

2, 303-331, 2005

\section{Pure stands of temperate forest tree species}

N. Brüggemann et al.



EGU 
The $\mathrm{pH}$ values of the soils of the species trial investigated in our study were generally so low that they probably superimposed any potential effect of the tree species on soil $\mathrm{pH}$. However, in general the stand-forming tree species can have a significant influence on the $\mathrm{pH}$ at least in the upper layers of the forest soil due to differences in 5 litter composition (Priha and Smolander, 1999). This influence on soil pH can have consequences for soil $\mathrm{C}$ and $\mathrm{N}$ turnover, as the $\mathrm{pH}$ has crucial effects on soil microbial processes (Persson and Wiren, 1993).

\subsection{Soil $\mathrm{C}$ and $\mathrm{N}$ turnover rates}

The soil respiration rates in our study were in the range of data published in the literature (e.g. Ross et al., 1999). This also applies for published gross rates of $\mathrm{N}$ mineralization (e.g. Hart et al., 1997; Tietema, 1998; Pedersen et al., 1999; Verchot et al., 2001). The gross rates of nitrification found in this work were basically of the same order of magnitude as other data reported by Barraclough and Puri (1995), Hart et al. (1997), Tietema (1998), Ingwersen et al. (1999) and Verchot et al. (2001). Only two values, de15 termined in the July samples of the organic layers under beech $\left(32 \mathrm{mg} \mathrm{N} \mathrm{kg}^{-1} \mathrm{sdw} \mathrm{d}^{-1}\right)$ and spruce $\left(40 \mathrm{mg} \mathrm{N} \mathrm{kg}^{-1} \mathrm{sdw} \mathrm{d}^{-1}\right.$ ) were higher than any previous value reported for temperate forests. Such high rates of gross nitrification have so far only been reported for tropical forest soils (Breuer et al., 2002). However, these two values were also afflicted with the highest standard error (Fig. 2c) due to a high small-scale variability of gross nitrification within the respective tree stand, with so-called hot spots of high microbial activity bordering on areas with much lower $\mathrm{N}$ turnover rates (Hesselsoe et al., 2001). For the incubation conditions chosen denitrification rates were very low as compared to gross mineralization and gross nitrification rates and were therefore not shown.

25 We studied gross rates of $\mathrm{N}$ mineralisation and nitrification to assess the full dynamics of these two processes, although the significance of gross rates for a survey of an effect of forest type on soil $\mathrm{N}$ cycling has been questioned (Verchot et al., 2001). But to our understanding, applying the widely accepted hole-in-the-pipe concept (Firestone
BGD

2, 303-331, 2005

Pure stands of temperate forest tree species

N. Brüggemann et al.



EGU 
and Davidson, 1989) for the assessment of $\mathrm{N}$ trace gas losses during $\mathrm{N}$ turnover requires the knowledge of gross rates. This view is also shared by other authors (e.g. Bengtsson et al., 2003).

\subsection{Relationships between soil respiration and gross $\mathrm{N}$ turnover rates}

5 In general, soil respiration, gross $\mathrm{N}$ mineralization and gross nitrification rates were much higher in the organic layers than in the $A_{h}$ horizons when expressed on a dry weight basis, which is also consistent with the literature (e.g. Pedersen et al., 1999; Ross et al., 1999; Verchot et al., 2001). This finding can be attributed to the much higher availability of fresh organic material and of $\mathrm{NH}_{4}^{+}$in the organic layer as com-

10 pared to the mineral soil. The significant differences in rates of soil respiration, gross $\mathrm{N}$ mineralization and gross nitrification rates between the spring and summer samples were accompanied by considerable differences in soil temperatures as well as in soil water contents between the two sampling dates. Both factors have been shown to have a significant influence on the magnitude of soil $\mathrm{C}$ and $\mathrm{N}$ turnover processes (e.g.

15 Persson and Wiren, 1993; Breuer et al., 2002), with higher rates of mineralisation and nitrification at higher temperatures and intermediate soil water content.

Soil respiration, gross $\mathrm{N}$ mineralization and gross nitrification rates showed a similar pattern with respect to differences between the organic layers and $A_{h}$ horizons, between spring and summer samples, and between the different tree stands. The close 20 relationship between soil respiration and gross nitrification rates points towards a tight coupling of $\mathrm{C}$ and $\mathrm{N}$ transformations in soils of forest ecosystems, such as the process of heterotrophic nitrification. A similar coupling has been reported earlier for net nitrification rates and substrate-induced respiration in soil depths greater than $10 \mathrm{~cm}$ in Siberian forest (Menyailo et al., 2002). A close relationship between N mineraliza25 tion and nitrification has also been observed e.g. by Hart et al. (1997) and Menyailo et al. (2002). Nevertheless, the tendency to higher gross nitrification rates compared to the respective gross $\mathrm{N}$ mineralization rates, as observed in this work, is not in accordance with data reported by Hart et al. (1997), Pedersen et al. (1999) and Verchot
BGD

2, 303-331, 2005

\section{Pure stands of temperate forest tree species}

N. Brüggemann et al.

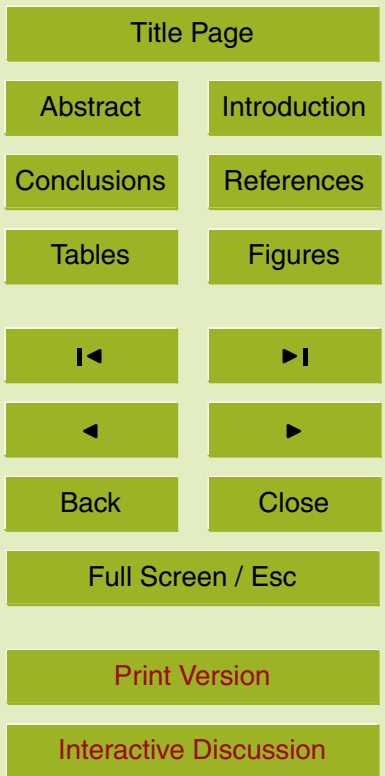

EGU 
et al. (2001). However, since the experimental plots are located in an area with substantial stock farming, one possible explanation for this unexpected finding might be a significant long term atmospheric supply of $\mathrm{NH}_{3}$ to the forest soil that enhances the soil $\mathrm{NH}_{4}^{+}$pool and, thus, allows higher nitrification than $\mathrm{N}$ mineralization rates at least 5 under suitable conditions. Especially during northerly winds $\mathrm{NH}_{3}$ is transported to the forest from the surrounding agricultural area (Hovmand et al., 1998; Andersen et al., 1999). Another reason could be a promotion of nitrification compared to $\mathrm{N}$ mineralization under the experimental conditions chosen. Dissimilatory reduction of $\mathrm{NO}_{3}^{-}$to $\mathrm{NH}_{4}^{+}$, thereby enhancing the ammonium pool, could be a third explanation. Although 10 this process is observed only under strictly anaerobic conditions (Silver et al., 2001), whilst nitrification is restricted to an aerobic environment, it cannot be excluded that both processes are active simultaneously, as soils can have well aerated macropores bordered by micropores with $\mathrm{O}_{2}$ deficiency (Smith, 1980). Furthermore, in soils with high microbial activity particularly active spots can suffer from $\mathrm{O}_{2}$ depletion (Parkin, 15 1987).

The significant differences in the $\mathrm{C}$ and $\mathrm{N}$ turnover between the different tree stands demonstrated that the dynamics of soil $\mathrm{C}$ and $\mathrm{N}$ transformation processes are indeed affected by different tree species. However, in this study we could not resolve to what extent different possible factors, such as differences in litter quality or soil temperature and moisture regimes, contributed to the observed differences in $\mathrm{C}$ and $\mathrm{N}$ transformations. Further studies are required to clarify the contribution of each of the factors, and to establish a broader database for the transfer of the results to other temperate climate regions. They should focus on (i) regional differences due to differences in climate, (ii) year-round measurements to capture seasonal dynamics, and (iii) soils with higher $\mathrm{pH}$ to assess a possible tree-species effect on the $\mathrm{pH}$ of the soil. The results of these investigations will lead to a better process understanding of soil $\mathrm{C}$ and $\mathrm{N}$ transformations and $\mathrm{C}$ and $\mathrm{N}$ trace gas production.

Acknowledgements. The work was supported by the European Commission's fifth framework program in the form of the NOFRETETE project (contract No. EVK2-CT2001-00106).

BGD

2, 303-331, 2005

Pure stands of temperate forest tree species

N. Brüggemann et al.



EGU 


\section{References}

Andersen, H. V., Hovmand, M., Hummelshøj, P., and Jensen, N. O.: Measurements of ammonia concentrations, fluxes and dry deposition velocities to a spruce forest 1991-1995, Atmos. Environ., 33, 1367-1383, 1999.

5 Andersen, H. V., Hovmand, M., Ro-Poulsen, H., Hansen, K., Pilegaard, K., Mikkelsen, T. N., Hummelshøj, P., Jensen, N. O., and Stenholt, C.: Atmosfærisk deposition til skove, in: Næringsstofkredsløb i skove - Ionbalanceprojektet, edited by: Hansen, K., For. Landsc. Res., 33, 33-67, 2003.

Andrews, J. A., Matamala, R., Westover, K. M., and Schlesinger, W. H.: Temperature effects on the diversity of soil heterotrophs and the delta $\mathrm{C}-13$ of soil-respired $\mathrm{CO}_{2}$, Soil Biol. Biochem., 32, 699-706, 2000.

Augusto, L., Ranger, J., Binkley, D., and Rothe, A.: Impact of several common tree species of European temperate forests on soil fertility, Ann. For. Sci., 59, 233-253, 2002.

Barraclough, D. and Puri, G.: The use of N-15 pool dilution and enrichment to separate the heterotrophic and autotrophic pathways of nitrification, Soil Biol. Biochem., 27, 17-22, 1995.

Bauhus, J., Pare, D., and Cote, L.: Effects of tree species, stand age and soil type on soil microbial biomass and its activity in a southern boreal forest, Soil Biol. Biochem., 30, 10771089, 1998.

Bengtsson, G., Bengtson, P., and Mansson, K. F.: Gross nitrogen mineralization-, immobilization-, and nitrification rates as a function of soil $\mathrm{C} / \mathrm{N}$ ratio and microbial activity, Soil Biol. Biochem., 35, 143-154, 2003.

Binkley, D. and Giardina, C.: Why do tree species affect soils? The Warp and Woof of tree-soil interactions, Biogeochem., 42, 89-106, 1998.

Breuer, L., Kiese, R., and Butterbach-Bahl, K.: Temperature and moisture effects on nitrification rates in tropical rain-forest soils, Soil Sci. Soc. Am. J., 66, 834-844, 2002.

Brooks, P. D., Stark, J. M., McInteer, B. B., and Preston, T.: Diffusion method to prepare soil extracts for automated N-15 analysis, Soil Sci. Soc. Am. J., 53, 1707-1711, 1989.

Coté, L., Brown, S., Pare, D., Fyles, J., and Bauhus, J.: Dynamics of carbon acid nitrogen mineralization in relation to stand type, stand age and soil texture in the boreal mixedwood,

30 Soil Biol. Biochem., 32, 1079-1090, 2000.

Davidson, E. A., Hart, S. C., Shanks, C. A., and Firestone, M. K.: Measuring gross nitrogen mineralization, immobilization, and nitrification by $\mathrm{N}-15$ isotopic pool dilution in intact soil
BGD

2, 303-331, 2005

Pure stands of temperate forest tree species

N. Brüggemann et al.

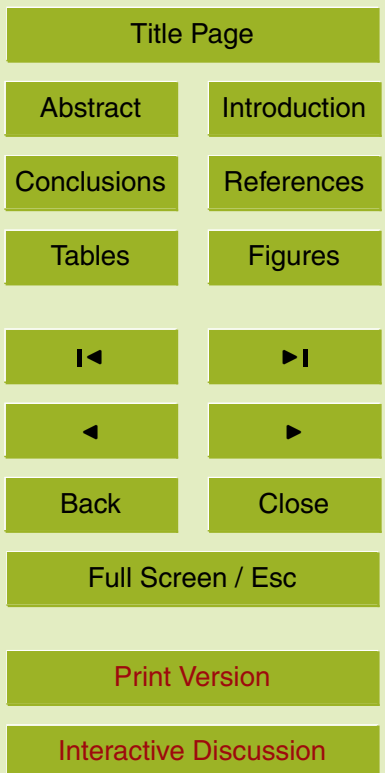

EGU 
cores, J. Soil Sci., 42, 335-349, 1991.

Erickson, H., Davidson, E. A., and Keller, M.: Former land-use and tree species affect nitrogen oxide emissions from a tropical dry forest, Oecologia, 130, 297-308, 2002.

Ferrari, J. B.: Fine-scale patterns of leaf litterfall and nitrogen cycling in an old-growth forest, Can. J. For. Res., 29, 291-302, 1999.

Firestone, M. K. and Davidson, E. A.: Microbiological basis of $\mathrm{NO}$ and $\mathrm{N}_{2} \mathrm{O}$ production and consumption in soil, in: Exchange of Trace Gases Between Terrestrial Ecosystems and the Atmosphere, edited by: Andreae, M. O. and Schimel, D. S., John Wiley, Chichester, pp. 7-21, 1989.

10 Gower, S. T. and Son, Y.: Differences in soil and leaf litterfall nitrogen dynamics for 5 forest plantations, Soil Sci. Soc. Am. J., 56, 1956-1966, 1992.

Hart, S. C., Binkley, D., and Perry, D. A.: Influence of red alder on soil nitrogen transformations in two conifer forests of contrasting productivity. Soil Biol. Biochem., 29, 1111-1123, 1997.

Hesselsoe, M., Pedersen, A., Bundgaard, K., Brandt, K. K., and Sorensen, J.: Development of nitrification hot-spots around degrading red clover (Trifolium pratense) leaves in soil, Biol. Fert. Soils, 33, 238-245, 2001.

Hovmand, M. F., Andersen, H. V., Løfstrøm, P., Ahleson, H., and Jensen, N. O.: Measurements of the horizontal gradient of ammonia over a conifer forest in Denmark, Atmos. Environ., 32, 423-429, 1998.

20 Ingwersen, J., Butterbach-Bahl, K., Gasche, R., Richter, O., and Papen, H.: Barometric process separation: New method for quantifying nitrification, denitrification, and nitrous oxide sources in soils, Soil Sci. Soc. Am. J., 63, 117-128, 1999.

Kiese, R., Papen, H., Zumbusch, E., and Butterbach-Bahl, K.: Nitrification activity in tropical rain forest soils of the Coastal Lowlands and Atherton Tablelands, Queensland, Australia, J. Plant Nutr. Soil Science-Zeitschrift für Pflanzenernährung und Bodenkunde, 165, 682-685, 2002.

Kirkham, D. and Bartholomew, W. V.: Equations for following nutrient transformations in soil utilizing tracer data, Soil Sci. Soc. Am. Pro., 18, 33-34, 1954.

Menyailo, O. V., Hungate, B. A., and Zech, W.: The effect of single tree species on soil microbial activities related to $\mathrm{C}$ and $\mathrm{N}$ cycling in the Siberian artificial afforestation experiment - Tree species and soil microbial activities, Plant Soil, 242, 183-196, 2002.

Menyailo, O. V., Hungate, B. A., Lehmann, J., Gebauer, G., and Zech, W.: Tree species of the central Amazon and soil moisture alter stable isotope composition of nitrogen and oxygen in
BGD

2, 303-331, 2005

Pure stands of temperate forest tree species

N. Brüggemann et al.

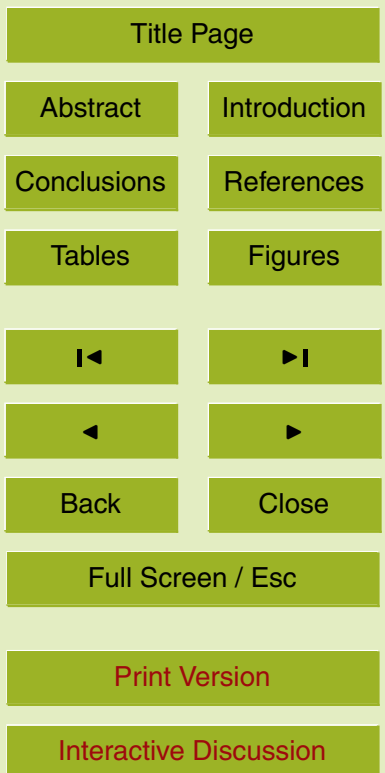

EGU 
nitrous oxide evolved from soil, Isot. Environ. Health Stud., 39, 41-52, 2003.

Michel, K. and Matzner, E.: Nitrogen content of forest floor $O_{a}$ layers affects carbon pathways and nitrogen mineralization, Soil Biol. Biochem., 34, 1807-1813, 2002.

Muys, B. and Lust, N.: Inventory of the earthworm communities and the state of litter decom5 position in the forests of Flanders, Belgium, and its implications for forest management, Soil Biol. Biochem., 24, 1677-1681, 1992.

Parker, G. G.: Throughfall and stemflow in the forest nutrition cycle, Adv. Ecol. Res., 13, 57133, 1983.

Parkin, T. B.: Soil microsites as a source of denitrification variability, Soil Sci. Soc. Am. J., 51, 1194-1199, 1987.

Pedersen, H., Dunkin, K. A., and Firestone, M. K.: The relative importance of autotrophic and heterotrophic nitrification in a conifer forest soil as measured by $\mathrm{N}-15$ tracer and pool dilution techniques, Biogeochem., 44, 135-150, 1999.

Persson, $\mathrm{T}$. and Wiren, A.: Effects of experimental acidification on $\mathrm{C}$ and $\mathrm{N}$ mineralization in forest soils, Agr. Ecosyst. Environ., 47, 159-174, 1993.

Priha, O. and Smolander, A.: Nitrogen transformations in soil under Pinus sylvestris, Picea abies and Betula pendula at two forest sites, Soil Biol. Biochem., 31, 965-977, 1999.

Priha, O., Lehto, T., and Smolander, A.: Mycorrhizas and $\mathrm{C}$ and $\mathrm{N}$ transformations in the rhizospheres of Pinus sylvestris, Picea abies and Betula pendula seedlings, Plant Soil, 206, 191-204, 1998.

Priha, O., Grayston, S. J., Pennanen, T., and Smolander, A.: Microbial activities related to $\mathrm{C}$ and $\mathrm{N}$ cycling and microbial community structure in the rhizospheres of Pinus sylvestris, Picea abies and Betula pendula seedlings in an organic and mineral soil, FEMS Microbiol. Ecol., 30, 187-199, 1999.

Ross, D. J., Kelliher, F. M., and Tate, K. R.: Microbial processes in relation to carbon, nitrogen and temperature regimes in litter and a sandy mineral soil from a central Siberian Pinus sylvestris L. forest, Soil Biol. Biochem., 31, 757-767, 1999.

Rothe, A.: Einfluss des Baumartenanteils auf Durchwurzelung, Wasserhaushalt, Stoffhaushalt und Zuwachsleistung eines Fichten-Buchen-Mischbestandes am Standort Höglwald, Forstl.

$30 \quad$ Forschungsber. Münch., 163, 1-174, 1997.

Rustad, L. E., Campbell, J. L., Marion, G. M., Norby, R. J., Mitchell, M. J., Hartley, A. E., Cornelissen, J. H. C., and Gurevitch, J.: GCTE-NEWS: A meta-analysis of the response of soil respiration, net nitrogen mineralization, and aboveground plant growth to experimental
BGD

2, 303-331, 2005

Pure stands of temperate forest tree species

N. Brüggemann et al.

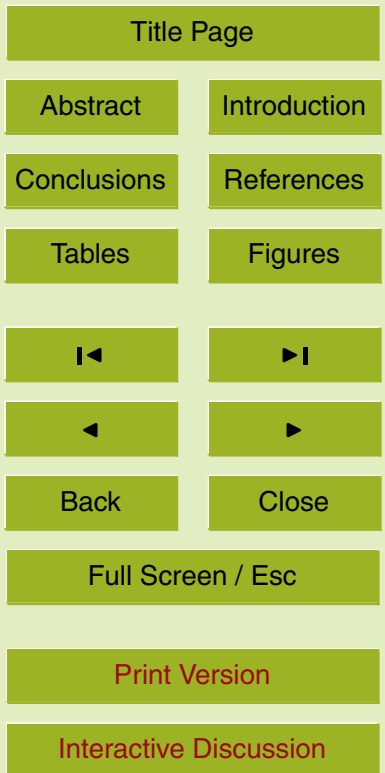

EGU 
ecosystem warming, Oecologia, 126, 543-562, 2001.

Scott, N. A. and Binkley, D.: Foliage litter quality and annual net N mineralization - comparison across North American forest sites [Review], Oecologia, 111, 151-159, 1997.

Silver, W. L., Herman, D. J., and Firestone, M. K.: Dissimilatory nitrate reduction to ammonium in upland tropical forest soils, Ecology, 82, 2410-2416, 2001.

Smith, K. A.: A model of the extent of anaerobic zones in aggregated soils and its potential application to estimates of denitrification, J. Soil Sci., 31, 263-277, 1980.

Ste-Marie, C. and Paré, D.: Soil, pH and $\mathrm{N}$ availability effects on net nitrification in the forest floors of a range of boreal forest stands, Soil Biol. Biochem., 31, 1579-1589, 1999.

Stump, L. M. and Binkley, D.: Relationships between litter quality and nitrogen availability in Rocky-Mountain forests, Can. J. For. Res., 23, 492-502, 1993.

Thomas, K. D. and Prescott, C. E.: Nitrogen availability in forest floors of three tree species on the same site: the role of litter quality, Can. J. For. Res., 30, 1698-1706, 2000.

Tietema, A.: Microbial carbon and nitrogen dynamics in coniferous forest floor material col15 lected along a European nitrogen deposition gradient, For. Ecol. Manage., 101, 29-36, 1998.

Verchot, L. V., Holmes, Z., Mulon, L., Groffman, P. M., and Lovett, G. M.: Gross vs. net rates of $\mathrm{N}$ mineralization and nitrification as indicators of functional differences between forest types, Soil Biol. Biochem., 33, 1889-1901, 2001.
BGD

2, 303-331, 2005

Pure stands of temperate forest tree species

N. Brüggemann et al.



Full Screen / Esc

Print Version

Interactive Discussion 
Pure stands of temperate forest tree species

N. Brüggemann et al.

Table 1. Thickness of the organic layer and in situ soil temperatures $5 \mathrm{~cm}$ below the surface under the five tree species investigated.

\begin{tabular}{lccccc}
\hline & Spruce & Beech & Larch & Oak & Pine \\
\hline Organic layer [cm] & $5.7 \pm 0.5^{a}$ & $6.3 \pm 0.9$ & $8.0 \pm 0.3$ & $3.8 \pm 0.5$ & $4.4 \pm 0.7$ \\
Soil temperature April $\left[{ }^{\circ} \mathrm{C}\right]$ & $7.5 \pm 0.1$ & $7.7 \pm 0.1$ & $8.4 \pm 0.2$ & $8.5 \pm 0.2$ & $8.5 \pm 0.3$ \\
Soil temperature July [ $\left.{ }^{\circ} \mathrm{C}\right]$ & $11.9 \pm 0.0$ & $12.3 \pm 0.1$ & $13.0 \pm 0.1$ & $13.3 \pm 0.1$ & $14.2 \pm 0.1$
\end{tabular}

${ }^{a}$ Values are means \pm SEM $(\mathrm{N}=6)$.



Full Screen / Esc

Print Version

Interactive Discussion 
Table 2. Values of maximum water holding capacity (MWHC, $\mathrm{g} \mathrm{H}_{2} \mathrm{O} 100 \mathrm{~g}^{-1}$ soil dry weight) and soil water content (SWC, $\mathrm{g} \mathrm{H}_{2} \mathrm{O} 100 \mathrm{~g}^{-1}$ soil dry weight) of the soil samples prior to the start of the experiments.

\begin{tabular}{lcccccccc}
\hline & MWHC (organic layer) & \multicolumn{2}{c}{ SWC (organic layer) } & \multicolumn{2}{c}{ MWHC $\left(A_{h}\right.$ horizon) } & \multicolumn{2}{c}{ SWC $\left(A_{h}\right.$ horizon) } \\
\hline & April & July & April & July & April & July & April & July \\
\hline Spruce & $389.2 \pm 45.8^{a}$ & $669.8 \pm 30.2$ & $48.2 \pm 6.2$ & $211.0 \pm 38.8$ & $56.7 \pm 7.1$ & $62.8 \pm 5.6$ & $14.4 \pm 0.8$ & $22.3 \pm 2.0$ \\
Beech & $473.9 \pm 66.5$ & $832.8 \pm 61.9$ & $207.5 \pm 28.6$ & $328.2 \pm 35.1$ & $72.7 \pm 4.6$ & $59.7 \pm 3.7$ & $32.2 \pm 5.0$ & $26.0 \pm 1.6$ \\
Larch & $741.8 \pm 6.7$ & $748.2 \pm 56.7$ & $177.3 \pm 11.3$ & $268.9 \pm 13.7$ & $59.5 \pm 3.1$ & $49.5 \pm 1.1$ & $18.5 \pm 2.1$ & $19.1 \pm 1.6$ \\
Oak & $330.6 \pm 82.5$ & $363.7 \pm 60.6$ & $102.0 \pm 24.2$ & $170.9 \pm 6.1$ & $70.3 \pm 2.1$ & $52.6 \pm 5.5$ & $29.6 \pm 3.1$ & $26.8 \pm 0.9$ \\
Pine & $299.0 \pm 23.6$ & $421.4 \pm 30.0$ & $133.3 \pm 33.4$ & $196.5 \pm 29.9$ & $68.3 \pm 6.4$ & $54.2 \pm 4.9$ & $25.8 \pm 2.6$ & $26.2 \pm 1.2$ \\
\hline
\end{tabular}

${ }^{a}$ Values are means \pm SEM ( $\mathrm{N}=3$ for MWHC, $\mathrm{N}=6$ for $\left.\mathrm{SWC}\right)$.
Pure stands of temperate forest tree species

N. Brüggemann et al.

Title Page

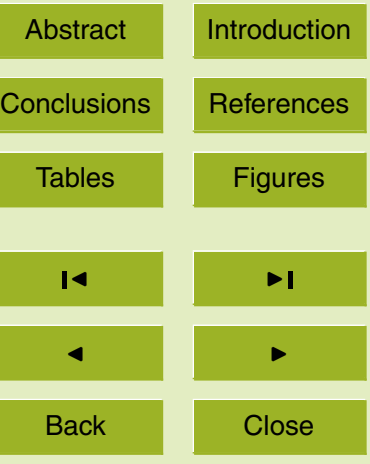

Full Screen / Esc

Print Version

Interactive Discussion 
Table 3. Total organic $\mathrm{C}$ content, total $\mathrm{N}$ content and total organic $\mathrm{C}$ to total $\mathrm{N}$ ratios of the organic layers and $A_{h}$ horizons under the five tree species studied.

\begin{tabular}{lcccccccc}
\hline \multicolumn{9}{c}{ Organic layer } \\
\hline & $\mathrm{pH}\left(\mathrm{CaCl}_{2}\right)$ & $\mathrm{C}[\%]$ & $\mathrm{N}[\%]$ & $\mathrm{C}$ to N & $\mathrm{pH}$ & $\mathrm{C}[\%]$ & $\mathrm{N}[\%]$ & $\mathrm{C}$ to N \\
\hline Spruce & $3.07 \pm 0.07^{a}$ & $42.59 \pm 4.15$ & $1.82 \pm 0.12$ & $23.30 \pm 0.78$ & $3.47 \pm 0.09$ & $3.64 \pm 0.46$ & $0.19 \pm 0.02$ & $19.60 \pm 0.61$ \\
Beech & $3.14 \pm 0.10$ & $46.56 \pm 2.28$ & $2.29 \pm 0.08$ & $20.30 \pm 0.42$ & $3.31 \pm 0.08$ & $4.40 \pm 0.49$ & $0.21 \pm 0.02$ & $21.10 \pm 0.75$ \\
Larch & $3.11 \pm 0.04$ & $49.30 \pm 2.13$ & $1.72 \pm 0.07$ & $28.63 \pm 0.70^{b}$ & $3.52 \pm 0.10$ & $2.47 \pm 0.30$ & $0.13 \pm 0.00$ & $19.07 \pm 1.85$ \\
Oak & $3.22 \pm 0.08$ & $38.20 \pm 5.03$ & $2.06 \pm 0.32$ & $18.67 \pm 0.52$ & $3.28 \pm 0.06$ & $3.07 \pm 0.10$ & $0.18 \pm 0.01$ & $17.60 \pm 0.10$ \\
Pine & $3.23 \pm 0.08$ & $29.33 \pm 9.88$ & $1.40 \pm 0.42$ & $20.57 \pm 0.94$ & $3.53 \pm 0.09$ & $2.89 \pm 0.24$ & $0.16 \pm 0.01$ & $17.93 \pm 0.13$ \\
\hline
\end{tabular}

${ }^{a}$ Values are means $\pm \mathrm{SEM}$ ( $\mathrm{N}=6$ for $\mathrm{pH}, \mathrm{N}=3$ for $\mathrm{C}$ and $\mathrm{N}$ contents and $\mathrm{C}$ to $\mathrm{N}$ ratios).

${ }^{b}$ Value is significantly higher than the other values in this column $(\mathrm{P}<0.05)$.
Pure stands of temperate forest tree species

N. Brüggemann et al.



Full Screen / Esc

Print Version

Interactive Discussion 
Pure stands of temperate forest tree species

N. Brüggemann et al.

Table 4. Pearson coefficients of the correlation between soil respiration, gross $\mathrm{N}$ mineralization and gross nitrification in the organic layers $(O)$ and in the first $5 \mathrm{~cm}$ of the mineral soils $\left(A_{h}\right)$.

\begin{tabular}{lcccccc}
\hline & & Spruce & Beech & Larch & Oak & Pine \\
\hline Gross N mineralization vs. & $\mathrm{O}$ & $0.722^{*}$ & $0.919^{\star \star}$ & $0.751^{*}$ & 0.483 & 0.146 \\
soil respiration & $A_{h}$ & 0.582 & 0.282 & 0.318 & 0.118 & 0.275 \\
Gross nitrification vs. & $\mathrm{O}$ & $0.920^{\star \star *}$ & $0.931^{\star \star *}$ & $0.713^{\star}$ & $0.921^{\star \star \star}$ & $0.720^{\star}$ \\
soil respiration & $A_{h}$ & 0.114 & 0.716 & 0.111 & 0.257 & $0.688^{*}$ \\
Gross nitrification vs. & $\mathrm{O}$ & 0.653 & $0.788^{\star}$ & 0.576 & 0.475 & 0.305 \\
gross N mineralization & $A_{h}$ & 0.304 & 0.223 & 0.663 & 0.144 & 0.344 \\
\hline
\end{tabular}

*: $P<0.05 ;{ }^{* *}: P<0.01 ;{ }^{* \star *}: P<0.001$

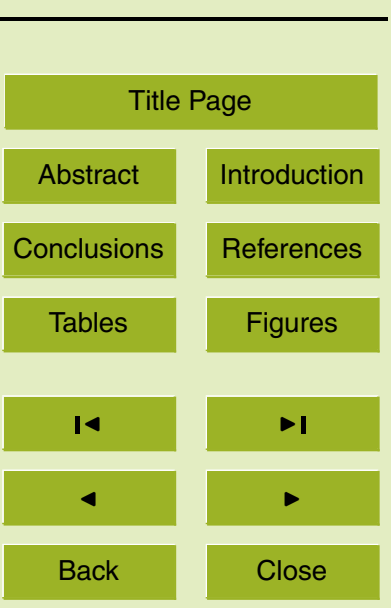

Full Screen / Esc

Print Version

Interactive Discussion 


\section{BGD}

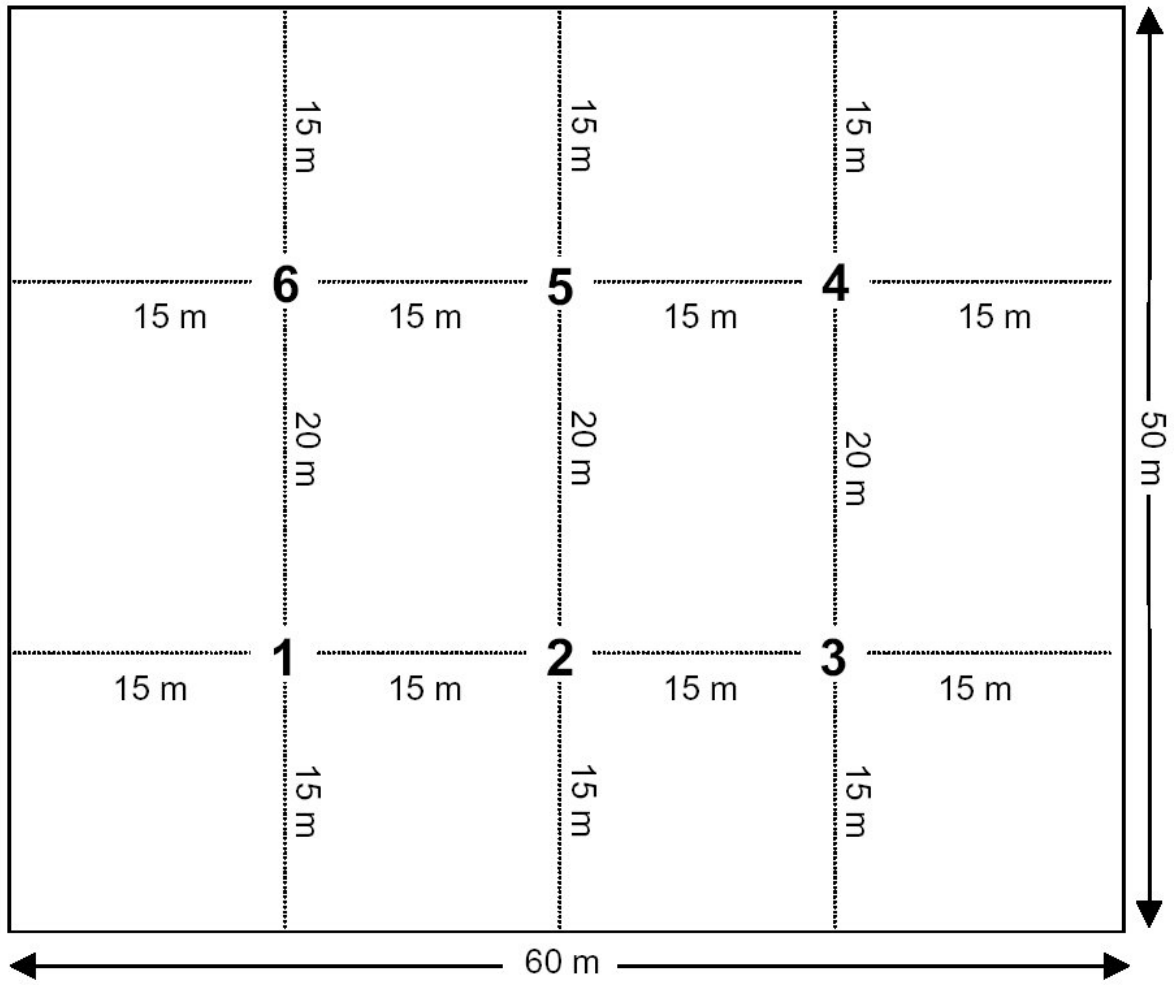

2, 303-331, 2005

Pure stands of temperate forest tree species

N. Brüggemann et al.

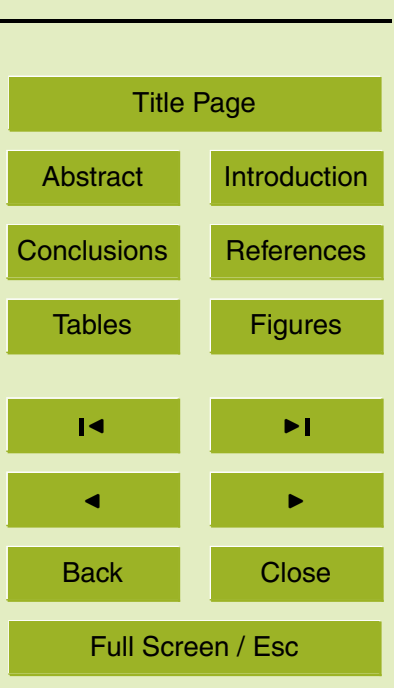

Fig. 1. Scheme of each of the five tree stands of the species trial investigated. The bold

Print Version

numbers indicate the six sampling locations. 


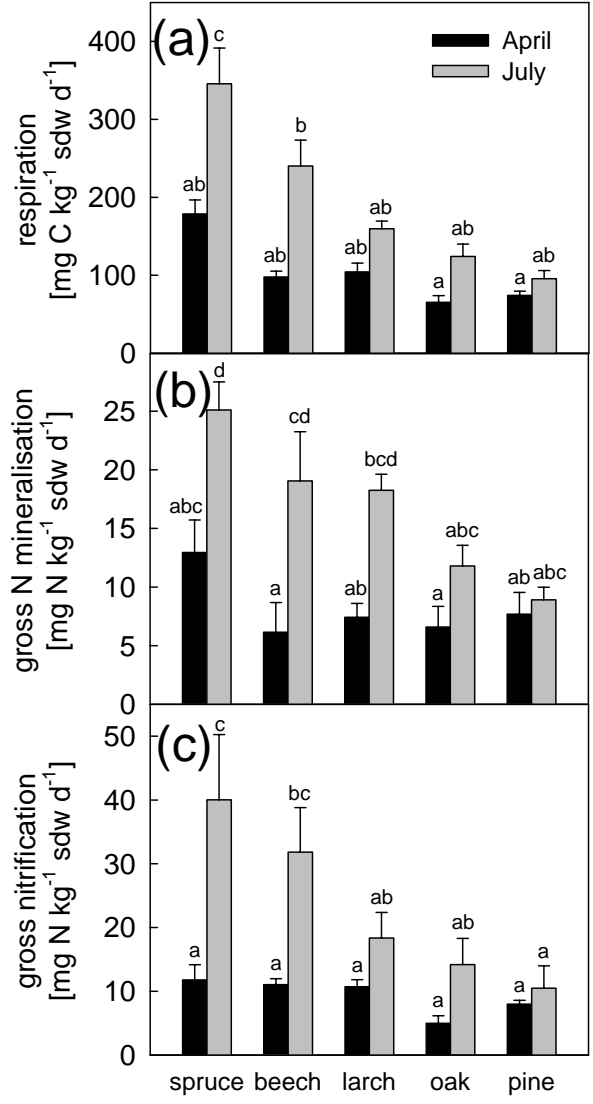

Fig. 2. Rates of (a) $\mathrm{CO}_{2}$ release, (b) gross $\mathrm{N}$ mineralization and (c) gross nitrification denitrification in the organic layer in soils sampled on 23 April and on 2 July, 2002, from each of the five tree stands investigated. For gross mineralization $n=5, \pm S E M$; for all other rates $n=6$, \pm SEM. Significant differences $(P<0.05)$ between the mean values are indicated by different letters; n.d.=not detected.
BGD

2, 303-331, 2005

Pure stands of temperate forest tree species

N. Brüggemann et al.

\section{Title Page}

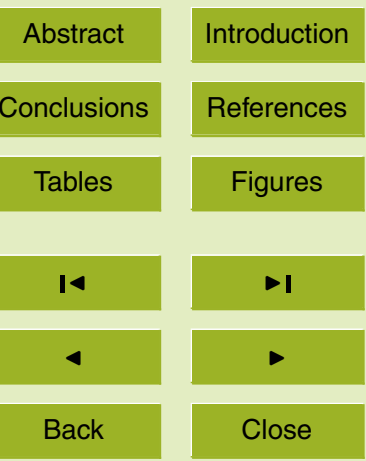

Full Screen / Esc

Print Version

Interactive Discussion 




Fig. 3. Rates of (a) $\mathrm{CO}_{2}$ release, (b) gross $\mathrm{N}$ mineralization and (c) gross nitrification denitrification in the first $5 \mathrm{~cm}$ of the $A_{h}$ horizon in soils sampled on 23 April and on 2 July, 2002, from each of the five tree stands investigated. For gross mineralization $n=5, \pm S E M$; for all other rates $\mathrm{n}=6, \pm$ SEM. Significant differences $(P<0.05)$ between the mean values are indicated by different letters.
BGD

2, 303-331, 2005

Pure stands of temperate forest tree species

N. Brüggemann et al.

\section{Title Page}

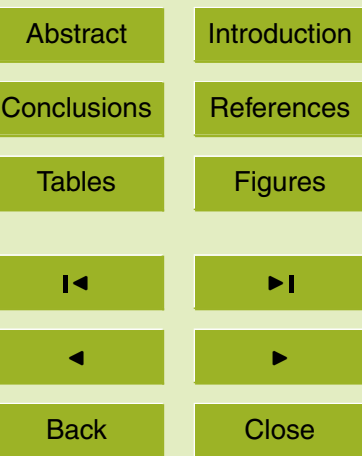

Full Screen / Esc

Print Version

Interactive Discussion 

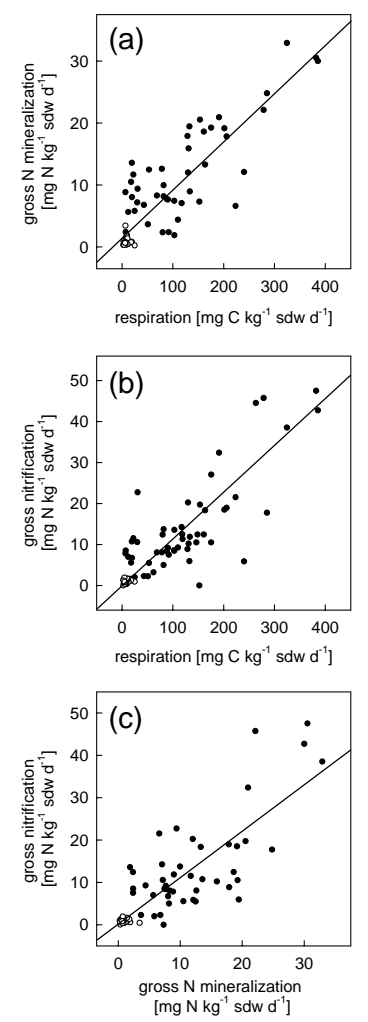

Fig. 4. Correlation between (a) gross mineralization and $\mathrm{CO}_{2}$ release $\left(\mathrm{n}=86 ; r^{2}=0.77\right.$, $P<0.0001)$, (b) gross nitrification and $\mathrm{CO}_{2}$ release $\left(\mathrm{n}=106, r^{2}=0.81, P<0.0001\right)$, and (c) gross nitrification and gross mineralization $\left(\mathrm{n}=85, r^{2}=0.72, P<0.0001\right)$. For the regression analysis the values of all samples from all five tree stands were taken, comprising samples of April and July as well as of the organic layers $(\bullet)$ and the $A_{h}$ horizons $(\bigcirc)$.

\section{BGD}

2, 303-331, 2005

Pure stands of temperate forest tree species

N. Brüggemann et al.

\section{Title Page}

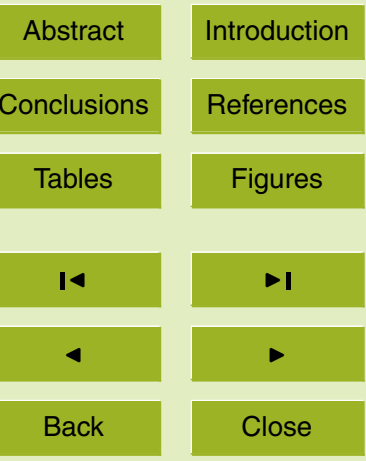

\section{Full Screen / Esc}

Print Version

Interactive Discussion

\section{EGU}

